\title{
Evaluation and Demonstration of Stormwater Dry Wells and Cisterns in Millburn Township, New Jersey
}

\author{
Leila Talebi and Robert Pitt
}

\begin{abstract}
Since 1999, the Township of Millburn has required dry wells to accommodate additional flows from newly developed areas in order to mitigate local drainage and water quality problems. The primary objective of this USEPA funded project was to investigate the effectiveness of the Township of Millburn's use of on-site dry wells to limit stormwater flows into the local drainage system. This objective was achieved by collecting and monitoring the performance of dry wells during both short and long periods. The water quality beneath dry wells and in a storage cistern was also monitored during ten rain events. There were varying levels of dry well performance in the area, but most were able to completely drain within a few days. However, several had extended periods of standing water that may have been associated with high water tables, poorly draining soils (or partially clogged soils), or detrimental effects from snowmelt on the clays in the soils. The infiltration rates all met the infiltration rate criterion of the state guidelines for stormwater discharges to dry wells, but not the state regulations that allow only roof runoff to be discharged to dry wells and those that prohibit dry well use in areas of shallow water tables. Overall, most of the Millburn dry wells worked well in infiltrating runoff. The findings reported in this paper indicate that the dry wells did not significantly change any of the water quality concentrations of the effluent water compared to the influent water. The cistern system did result in significant reductions in bacteria levels. Although the dry wells provided no significant improvements in water quality for constituents of interest in the infiltrating water, they resulted in reduced mass discharges of flows and pollutants to surface waters and reduced runoff energy, a major cause of local erosion problems.
\end{abstract}

Keywords: stormwater, water quality, LID-BMP, monitoring.

\section{Description of Millburn and its Dry Wells}

Millburn Township, in Essex County New Jersey, is located near New York City, and is $<10$ miles ( $16 \mathrm{~km}$ ) from Newark International Airport. The 2010 United States census indicated the township had a population of 20149 . Housing costs are very high (according to Wikipedia, Millburn had the highest annual property tax bills in New Jersey in 2009, on average $>\$ 19000$ per year, compared to the statewide average property tax of $\$ 7300$ which was the highest statewide average in the country). There are about 5900 detached homes in the township and about 1500 have dry wells.

In 1999, the Township of Millburn created an ordinance that required increased runoff from new impervious areas to be directed into seepage pits (dry wells). The purpose of our project was to investigate the effectiveness of this ordinance; specifically to examine the use of dry wells as a technique to redirect surface runoff to local shallow groundwater. The objective of this practice is to reduce the local drainage and erosion problems associated with new development and the increase in impervious areas of currently developed areas. The slower release of the shallow groundwater to surface streams also better simulates natural hydrologic patterns with a reduction of in-stream problems associated with increased rapid surface runoff. The township has a stable population and there is little vacant land; all new construction within the community occurs on previously developed plots.

The Millburn Township stormwater regulations (in their Development Regulations) list dry wells as one option for minimizing increased flows associated with new (and increased) development. They do not include any specific criteria for their

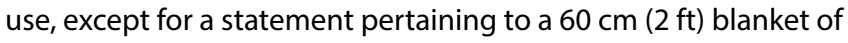
crushed stone surrounding the dry well. Specifically, they do not describe applicable soil characteristics, groundwater conditions or suitable source waters. The New Jersey stormwater regulations (NJDEP 2011) also require the infiltration of excess water above natural conditions associated with development or land modifications (either maintaining the pre-development groundwater recharge or preventing excess surface runoff). The state dry well regulations describe the construction of the dry wells, the acceptable soil conditions (NRCS hydrologic soil groups, HSG, A and B), groundwater conditions (at least $60 \mathrm{~cm}, 2 \mathrm{ft}$, above the seasonal water table) and source waters (roof runoff only).

A dry well is a subsurface infiltration stormwater disposal practice that receives stormwater runoff from surrounding areas for subsurface disposal to shallow groundwater. Most of the dry wells in Millburn are precast concrete structures (Figure 1), with

Talebi, L. and R.E. Pitt. 2014. "Evaluation and Demonstration of Stormwater Dry Wells and Cisterns in Millburn Township, New Jersey." Journal of Water Management Modeling C376. doi: 10.14796/JWMM.C376.

(c) CHI 2014 www.chijournal.org ISSN: 2292-6062 


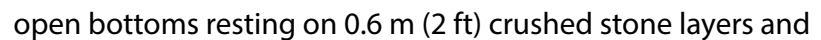
with $0.6 \mathrm{~m} \mathrm{(} 2 \mathrm{ft}$ ) crushed stone surrounding the dry wells. Most of the dry wells receive water directly from roof drain leaders or by storm drain inlets located in driveways or small parking lots. Some also have grated covers and receive surface runoff from the surrounding lawn or paved areas.

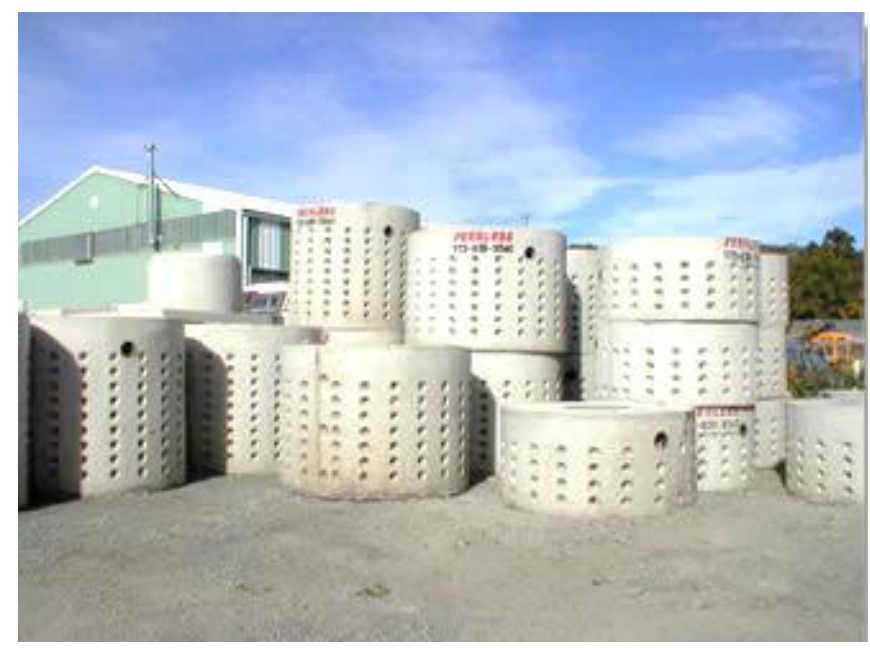

Figure 1 Peerless Concrete Products, Butler NJ supplies the dry wells to many of the sites in Millburn (photo from http://www.peerlessconcrete.com/).

Figure 2 shows typical dry well installations. Many of the dry wells are located in landscaped areas and have open covers, allowing surface runoff from lawns to enter the dry wells, as well as the subsurface piped roof runoff. Some are also located in paved areas, also allowing surface runoff from driveways to enter along with the roof runoff.

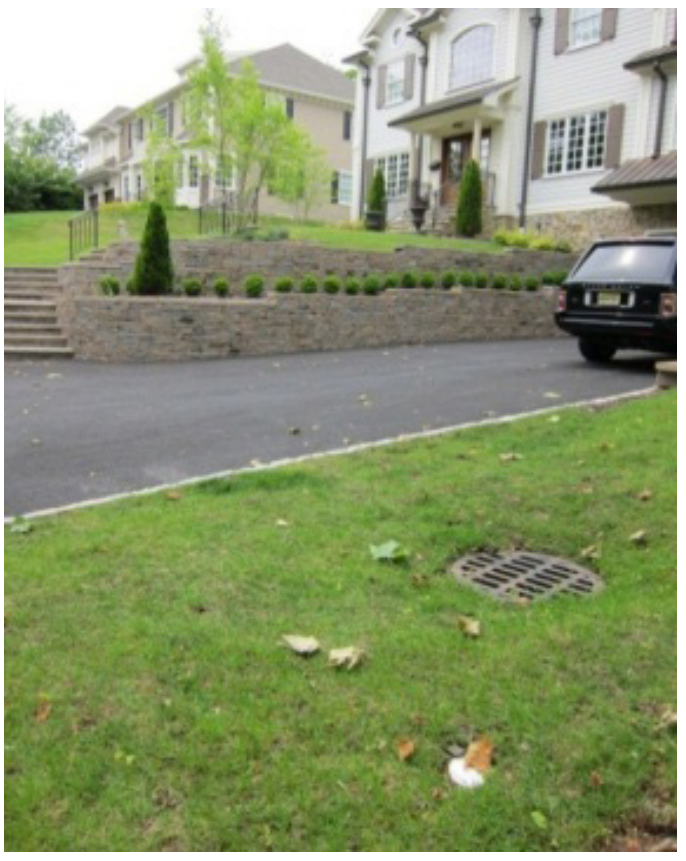

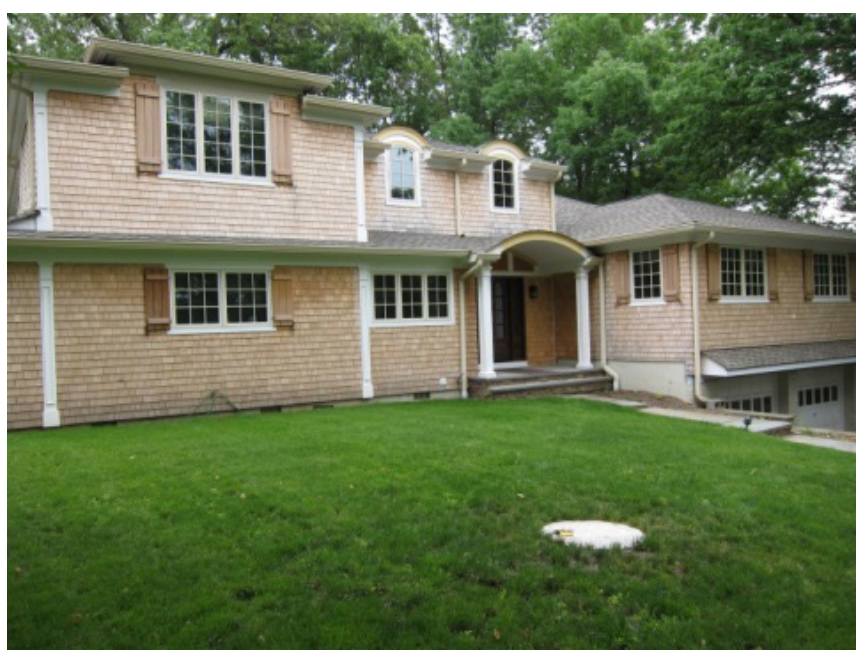

Figure 2 Typical Millburn dry well locations in front yards, receiving lawn area inflows along with roof runoff.

\section{Methodology}

\subsection{Infiltration Tests at Millburn Dry Well Instal- lations}

Infiltration tests were conducted during two project phases. The first phase filled the dry wells with domestic water from township fire hydrants and the decreasing water levels were recorded. The second phase used continuous water level monitoring in a smaller number of dry wells during many rains. The infiltration measurements were conducted using continuous recording (10 min observations) LeveLoggers by Solintest that were installed in the dry wells. In this study the short term tests were collected from eleven dry wells throughout the township to measure the influence of some of the conditions present in the community. The long term tests were conducted in fewer dry wells (based on the number of LeveLoggers available). These were installed for several months to over a year at each monitored location, and continuously recorded the water levels in the dry wells every 10 min during and between rains. Nearby rain gauges were also used to record local rains associated with these events. These rain and water level data were downloaded by PARS Environmental personnel and uploaded to their website where University of Alabama researchers downloaded the data for analysis.

The first step in the data analyses of the long term tests was to plot the data as time series. The infiltration characteristics of the dry well installations were calculated from the recession curves of these individual rain events. The infiltration rates for each 10 min step were calculated based on the drop in water level per time increment, resulting in infiltration rate plots of in./h vs time since the peak water level. These are classical infiltration rate plots and statistical analyses were used to calculate infiltration rate equation parameters for two common infiltration equations (Horton and Green-Ampt). 
Groundwater recharge is a suitable beneficial use of stormwater in many areas as it is used to augment local groundwater resources. This study showed how the dry wells could be very effective in delivering the stormwater to the groundwater. Even though the surface soils were almost all marginal for infiltration options, the relatively shallow dry wells were constructed into subsurface soil layers that had much greater infiltration potentials. However, some of the monitored dry well locations experienced seasonal high groundwater elevations, restricting the complete draining of the dry wells after rains. While surface and subsurface soil information is readily available for the township, the presence of the shallow water table (or bedrock) is not well known. This makes identifying the most suitable locations for dry wells difficult, as the seasonal groundwater should be at least $4 \mathrm{~m}$ $(12 \mathrm{ft})$ below the ground surface, or $0.60 \mathrm{~m}(2 \mathrm{ft})$ below the lowest gravel fill layer beneath the dry well (the depth is accounted for by: $2 \mathrm{ft}, 0.61 \mathrm{~m}$, of surface cover; $6 \mathrm{ft}, 1.8 \mathrm{~m}$, dry well concrete structure; $2 \mathrm{ft}, 0.61 \mathrm{~m}$, lower gravel layer; and $2 \mathrm{ft}, 0.61 \mathrm{~m}$, of separation above the high seasonal groundwater depth).

Calculating the benefits of the dry wells (including developing sizing requirements) requires the use of an appropriate infiltration equation, preferably as part of a continuous model examining many years of rainfall data for a specific area. Two commonly used infiltration equations (Horton and Green-Ampt) were evaluated for their potential use to calculate groundwater recharge at the case study locations in Millburn.

One of the most commonly used infiltration equations was developed by Horton (1940). The equation is:

$$
f=f_{c}+\left(f_{o}-f_{c}\right) e^{-k t}
$$

where

$$
\begin{aligned}
f & =\text { infiltration rate at time } t \text { (in./h), } \\
f_{o} & =\text { initial infiltration rate (in./h), } \\
f_{c} & =\text { final (constant) infiltration rate (in./h), and } \\
k & =\text { first order rate constant }\left(\mathrm{h}^{-1} \text { or } \min ^{-1}\right) .
\end{aligned}
$$

This equation assumes that the rainfall intensity is greater than the infiltration capacity at all times and that the infiltration rate decreases with time (Bedient and Huber 1992). This is a reasonable assumption for ponded conditions, such as in the dry wells. The capacity of the soil to hold additional water decreases as the time of the storm increases because the pores in the soil become saturated with water. The Horton equation's major drawback is that it does not consider the soil water storage availability after varying amounts of infiltration have occurred, but only considers infiltration as a function of time (Akan 1993). However, integrated forms of the equation can be used that do consider the amount of water added to the soil. It is recommended that $f_{c^{\prime}} f_{o^{\prime}}$ and $k$ all be obtained through field data, but they are rarely measured locally.

Another common equation for infiltration calculations is by Green and Ampt. The Green-Ampt equation calculates cumulative infiltration as the water flows into a vertical soil profile (Green and Ampt 1911).

$$
f_{t}=K\left(\frac{\psi \Delta \theta}{F_{t}}+1\right)
$$

where

$f_{t}=$ infiltration rate, $\mathrm{cm} / \mathrm{h}$,

$\psi=$ initial matric potential of the soil (in.),

$\Delta \theta=$ difference of soil water content after infiltration with initial water content (in. ${ }^{3} /$ in. $\left.^{3}\right)$,

$K=$ hydraulic conductivity (in./h); and

$F_{t}=$ cumulative infiltration at time $t$ (in.). $\left(1 / F_{t}\right)$.

This equation requires a linear relationship between $f_{t}$ and

\subsection{Water Quality Samplings}

Water samples were collected at three dry wells and at one cistern during ten rains. The samples were analyzed for nutrients and heavy metals, and selected samples were also tested for pesticides and herbicides. For the dry wells, the samples were collected directly below the dry wells for comparison to water

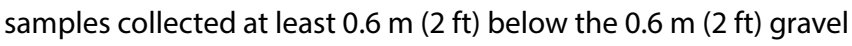
layer beneath the dry wells, for a total subsurface flow path of at

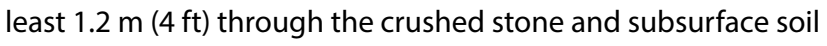
(more than the minimum $2 \mathrm{ft}, 0.6 \mathrm{~m}$, separation to the groundwater table as required by the New Jersey stormwater infiltration regulations). For the cistern, the samples were collected at the inlet of the cistern for comparison to samples collected from inside the cistern near the outlet. Various statistical tests were used to compare the water quality from the inlet to the outlet locations to detect any significant differences due to operation of the dry wells.

\section{Results and Discussions}

\subsection{Fitted Infiltration Equations Results for Mill- burn Dry Well Infiltration Measurements}

The initial infiltration data analysis was to prepare plots of the observed infiltration data in order to evaluate major trends and groupings of the data. Observed data included the water stage in dry wells at 10 min intervals. The differential values of water stages in a dry well for each event were divided by the time to calculate the infiltration rates as a function of time. Data from each site for each event or infiltration test was fitted to the Horton infiltration equation and the equation parameters were derived for $f_{o^{\prime}}$ the initial infiltration capacity, $f_{c^{\prime}}$ the constant infiltration capacity as $t$ approaches infinity, and $k$, a soil parameter that controls the rate of decrease of infiltration rate. For some of the sites, the Horton equation could not be fitted to the observed data, as little water level change occurred with time. This typically occurred for narrow ranges of the dry well water depth such as when standing water occurred due to shallow water tables. For these conditions, the observed rates most likely corresponded to the $f_{c}$ values, the saturated infiltration rate ( $f_{o}$ and $k$ were not calculated). Basic 
statistical analyses, including average, minimum, maximum, standard deviation, and COV are included in the full USEPA report (Pitt and Talebi 2012) for all the data, as well as ANOVA test and residual plots for some of the fitted Horton equations in comparison to the Green-Ampt equation.

Figure 3 shows the observed infiltration rates and the fitted Horton equation parameter values for the dry well located at 7 Fox Hill Lane, Millburn, New Jersey for an example rain event. Graphs are for an actual rain event representing observed data, fitted Horton equations, rain depths, and the water stage in the dry well.
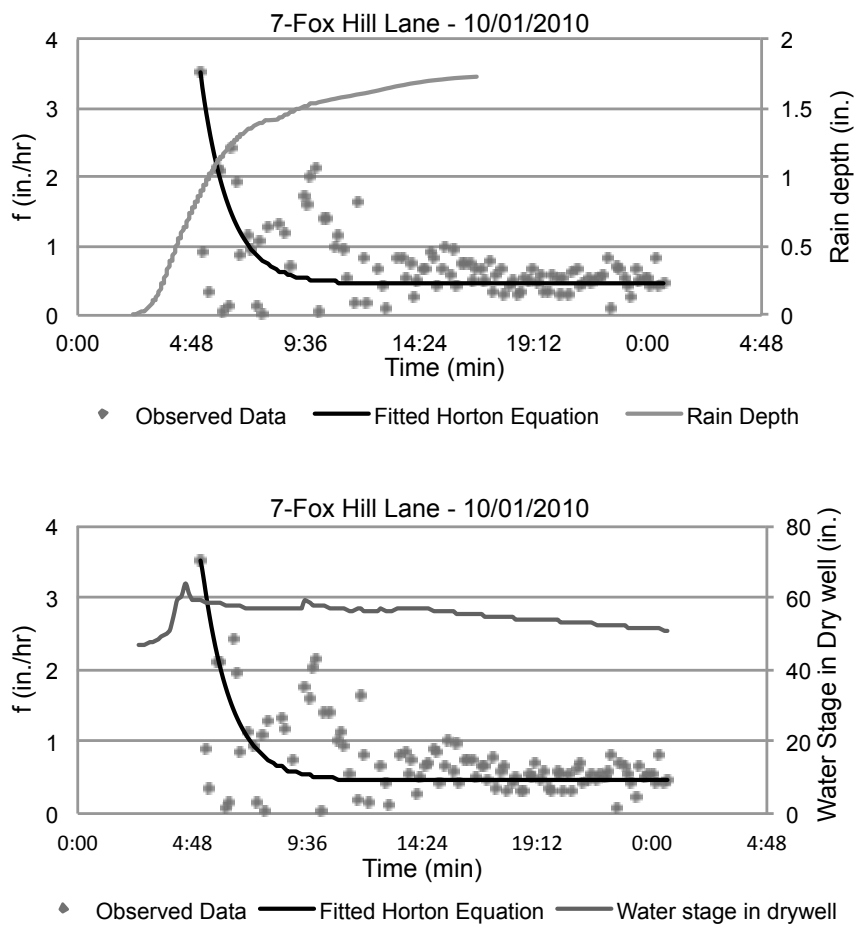

Figure 3 Example of observed data, fitted Horton equation, rain depth and water stage in a dry well for three different rain events in a selected dry well $(1 \mathrm{in} . / \mathrm{h}, 25.4$ $\mathrm{mm} / \mathrm{h})$.

Multiple iterations of grouped box and whisker plots and ANOVA tests were used to identify data groupings. The data were not normally distributed so ANOVA based on ranks and MannWhitney rank sum nonparametric tests were used to calculate the significance that the data did not originate from the same populations.

There were two distinct sets for the $f_{c}$ data: the 258 Main Street location vs all of the other sites combined. Figure 4 shows these two data sets.

The results of the final Mann-Whitney rank sum test for $f_{c}$ are shown in Table 1.

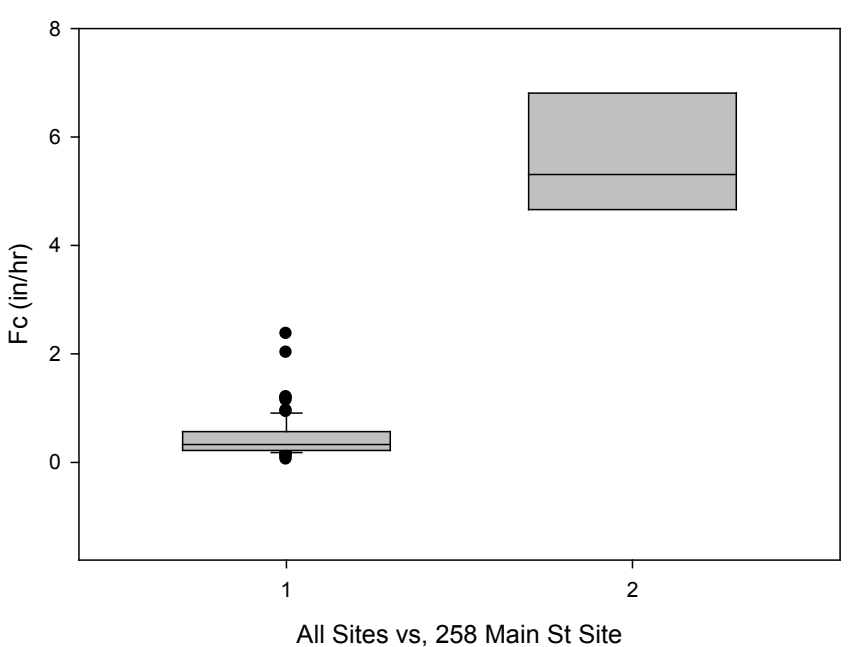

Figure 4 Box and whisker plot of $f_{c}$ data showing two sets of data (1 in./h, $25.4 \mathrm{~mm} / \mathrm{h})$.

Table 1 Results of the final Mann-Whitney rank sum test for $f_{c}$.

\begin{tabular}{lccccc}
\hline \multicolumn{1}{c}{ Group } & $\mathrm{N}$ & Missing & Median & $25 \%$ & $75 \%$ \\
\hline Combined & 81 & 0 & 0.33 & 0.22 & 0.57 \\
258 Main Street & 3 & 0 & 5.31 & 4.66 & 6.81 \\
\hline
\end{tabular}

Mann-Whitney U Statistic $=0.000 ; \quad T=249.000 ; n($ small $)=3 ; n($ big $)=81 ; P=0.004$.

The difference in the median values between the two groups is greater than would be expected by chance; there is a statistically significant difference, with $P=0.004$. Tables 2 and 3 summarize the values and test conditions for these two sets of data.

Table $2 f_{c}$ summary values and conditions for 258 Main Street.

\begin{tabular}{lcccc}
\hline & $f_{c}$ (in./h) & $\begin{array}{c}\text { Rain Depth } \\
\text { (in.) }\end{array}$ & $\begin{array}{c}\text { Max. depth of water in } \\
\text { dry well (in.) }\end{array}$ & $\begin{array}{c}\text { Min. depth of water in } \\
\text { dry well (in.) }\end{array}$ \\
\hline Number & 3 & 3 & 3 & 3 \\
Minimum & 4.66 & 0.69 & 22.32 & 0.11 \\
Maximum & 6.81 & 1.34 & 54.77 & 0.67 \\
Average & 5.59 & 1.08 & 43.57 & 0.44 \\
Median & 5.31 & 1.22 & 53.62 & 0.53 \\
Std Dev & 1.10 & 0.35 & 18.41 & 0.29 \\
COV & 0.20 & 0.32 & 0.42 & 0.67 \\
\hline
\end{tabular}

1 in. $=25.4 \mathrm{~mm}$

Table $3 f_{o}$ summary values and conditions for 258 Main Street.

\begin{tabular}{lcccc}
\hline & $f_{c}$ (in./h) & $\begin{array}{c}\text { Rain Depth } \\
\text { (in.) }\end{array}$ & $\begin{array}{c}\text { Max. depth of water in } \\
\text { dry well (in.) }\end{array}$ & $\begin{array}{c}\text { Min. depth of water in } \\
\text { dry well (in.) }\end{array}$ \\
\hline Number & 81 & 63 & 81 & 81 \\
Minimum & 0.05 & 0.22 & 6.51 & 0.00 \\
Maximum & 2.37 & 2.90 & 93.85 & 82.98 \\
Average & 0.45 & 1.20 & 50.45 & 20.88 \\
Median & 0.33 & 1.15 & 53.76 & 10.07 \\
Std Dev & 0.38 & 0.76 & 22.93 & 24.15 \\
CoV & 0.85 & 0.63 & 0.45 & 1.16 \\
\hline 1 in. $=25.4 \mathrm{~mm}$ & & & &
\end{tabular}


Similar tests were conducted to identify significant groups for the $f_{o}$ data. Figure 5 is the final box and whisker plot, showing the two data groups: 258 Main Street, and 8 South Beechcroft vs all the data combined. The values are summarized in Table 4.

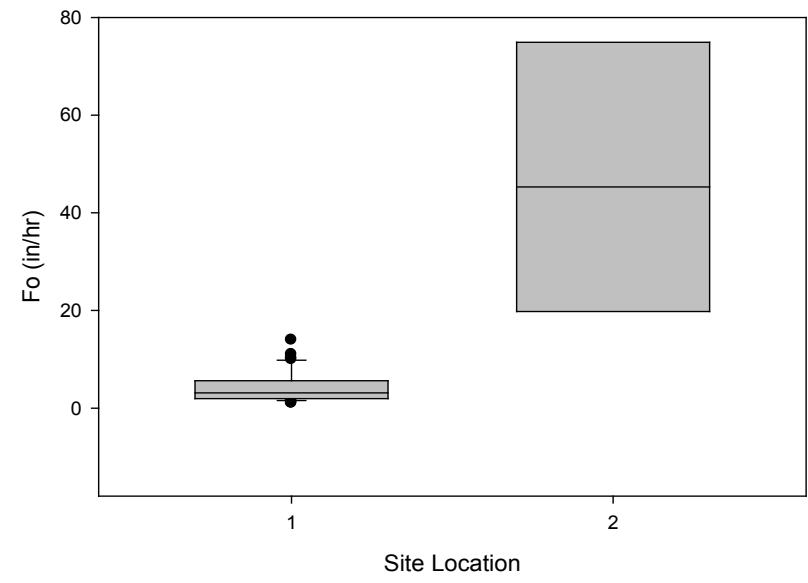

Figure 5 Box and whisker plot of $f_{o}$ data showing two sets of data.

Table 4 The results of the final Mann-Whitney rank sum test for $f_{0}$.

\begin{tabular}{lccccc}
\hline \multicolumn{1}{c}{ Group } & $\mathrm{N}$ & Missing & Median & $25 \%$ & $75 \%$ \\
\hline Combined & 43 & 0 & 3.12 & 1.94 & 5.63 \\
258 Main Street \& 8 & 7 & 0 & 45.29 & 19.78 & 74.92 \\
South Beechcroft Road & 7 & &
\end{tabular}

The difference in the median values between the two groups is greater than would be expected by chance; there is a statistically significant difference: $P<0.001$. Tables 5 and 6 summarize the values and test conditions for these two sets of data.

Similar tests were conducted to identify significant groups for the $k$ data. Figure 6 is the final box and whisker plot, showing the two data groups: 258 Main Street vs all the other data combined. The values are given in Table 7.

Table $5 f_{o}$ summary values and conditions for 258 Main Street and 8 South Beechcroft Road.

\begin{tabular}{lcccc}
\hline & $f_{c}$ (in./h) & $\begin{array}{c}\text { Rain Depth } \\
\text { (in.) }\end{array}$ & $\begin{array}{c}\text { Max. depth of water in } \\
\text { dry well (in.) }\end{array}$ & $\begin{array}{c}\text { Min. depth of water in } \\
\text { dry well (in.) }\end{array}$ \\
\hline Number & 7 & 6 & 7 & 7 \\
Minimum & 16.12 & 0.52 & 16.76 & 0.10 \\
Maximum & 75.14 & 1.71 & 54.77 & 1.94 \\
Average & 44.55 & 1.14 & 38.29 & 0.54 \\
Median & 45.29 & 1.28 & 41.29 & 0.32 \\
Std Dev & 23.74 & 0.45 & 14.98 & 0.65 \\
CoV & 0.53 & 0.39 & 0.39 & 1.21 \\
\hline 1 in. $=25.4 \mathrm{~mm}$ & & & &
\end{tabular}

1 in. $=25.4 \mathrm{~mm}$
Table $6 f_{o}$ summary values and conditions for 258 Main Street and 8 South Beechcroft Road.

\begin{tabular}{lcccc}
\hline & $f_{c}$ (in./h) & $\begin{array}{c}\text { Rain Depth } \\
\text { (in.) }\end{array}$ & $\begin{array}{c}\text { Max. depth of water in } \\
\text { dry well (in.) }\end{array}$ & $\begin{array}{c}\text { Min. depth of water in } \\
\text { dry well (in.) }\end{array}$ \\
\hline Number & 43 & 60 & 77 & 77 \\
Minimum & 1.01 & 0.22 & 6.51 & 0.00 \\
Maximum & 13.95 & 2.90 & 93.85 & 82.98 \\
Average & 4.34 & 1.20 & 51.28 & 21.93 \\
Median & 3.12 & 1.07 & 54.45 & 12.06 \\
Std Dev & 3.20 & 0.77 & 23.07 & 24.32 \\
CoV & 0.74 & 0.64 & 0.45 & 1.11 \\
\hline 1 in. $=25.4 \mathrm{~mm}$ & & & &
\end{tabular}

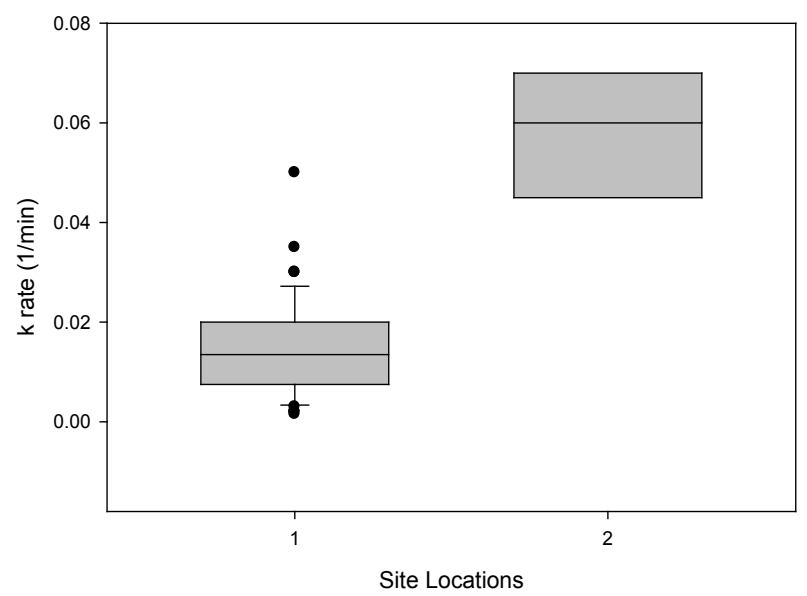

Figure 6 Box and whisker plot of $k$ data showing two sets of data.

Table 7 The results of the final Mann-Whitney rank sum test for $k$.

\begin{tabular}{lccccc}
\hline \multicolumn{1}{c}{ Group } & $\mathrm{N}$ & Missing & Median & $25 \%$ & $75 \%$ \\
\hline $\begin{array}{l}\text { Combined } \\
\text { 258 Main Street \& } 8\end{array}$ & 46 & 0 & 0.0135 & 0.0075 & 0.02 \\
$\begin{array}{l}\text { South Beechcroft Road } \\
\text { Mann-Whitney U Statistic= 1.000; }\end{array}$ & 3 & 0 & 0.06 & 0.045 & 0.07 \\
\hline
\end{tabular}

The difference in the median values between the two groups is greater than would be expected by chance; there is a statistically significant difference, with $P=0.005$. Tables 8 and 9 summarize the values and test conditions for these two sets of data.

The Green-Ampt equation calculates cumulative infiltration assuming water flowing into a vertical soil profile. Figure 7 is an example comparison between fitted Horton and Green-Ampt equations for one of the events at a selected dry well, as well as statistical analysis and residual plots. 


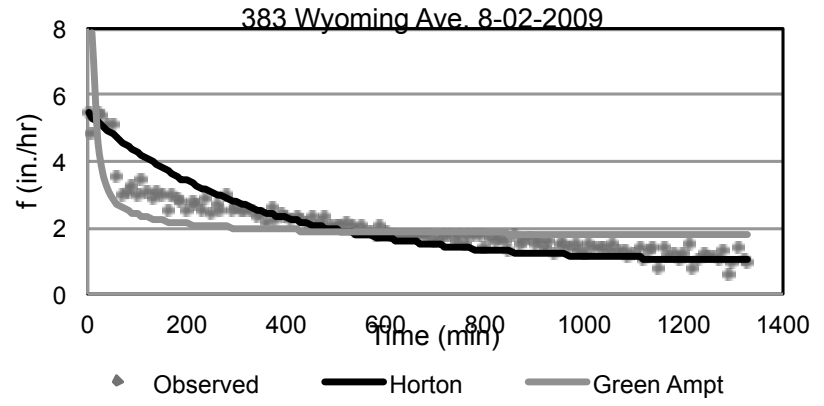

Figure 7 An example of fitted observed data to Horton equation and Green-Ampt equation (1 in., $25.4 \mathrm{~mm}$ ).

Table 8 summary values and conditions for 258 Main Street and 8 South Beechcroft Road.

\begin{tabular}{lcccc}
\hline & $k(1 / \mathrm{min})$ & $\begin{array}{c}\text { Rain Depth } \\
\text { (in.) }\end{array}$ & $\begin{array}{c}\text { Max. depth of water in } \\
\text { dry well (in.) }\end{array}$ & $\begin{array}{c}\text { Min. depth of water in } \\
\text { dry well (in.) }\end{array}$ \\
\hline Number & 3 & 3 & 3 & 3 \\
Minimum & 0.05 & 0.69 & 22.32 & 0.11 \\
Maximum & 0.07 & 1.34 & 54.77 & 0.67 \\
Average & 0.06 & 1.08 & 43.57 & 0.44 \\
Median & 0.06 & 1.22 & 53.62 & 0.53 \\
Std Dev & 0.01 & 0.35 & 18.41 & 0.29 \\
COV & 0.22 & 0.32 & 0.42 & 0.67
\end{tabular}

Table $9 k$ summary values and conditions for 258 Main Street and 8 South Beechcroft Road.

\begin{tabular}{lcccc}
\hline & $k(1 / \mathrm{min})$ & $\begin{array}{c}\text { Rain Depth } \\
\text { (in.) }\end{array}$ & $\begin{array}{c}\text { Max. depth of water in } \\
\text { dry well (in.) }\end{array}$ & $\begin{array}{c}\text { Min. depth of water in } \\
\text { dry well (in.) }\end{array}$ \\
\hline Number & 46 & 63 & 81 & 81 \\
Minimum & 0.002 & 0.22 & 6.51 & 0.00 \\
Maximum & 0.050 & 2.90 & 93.85 & 82.98 \\
Average & 0.014 & 1.20 & 50.45 & 20.88 \\
Median & 0.014 & 1.15 & 53.76 & 10.07 \\
Std Dev & 0.009 & 0.76 & 22.93 & 24.15 \\
CoV & 0.666 & 0.63 & 0.45 & 1.16
\end{tabular}

The results show that for most of the sites in this study, the Horton equation had a better fit to the data compared to the Green-Ampt equation for the Millburn data. However, for one site, the Green-Ampt equation provided a better fit. As noted previously, a linear relationship between $f_{t}$ and $\left(1 / F_{t}\right)$ is needed to determine the Green-Ampt equation parameters. The only visually acceptable linear regression is associated with the observations from the 258 Main Street site (the only location that had soils in the A group from the surface to about $1.1 \mathrm{~m}, 3.5 \mathrm{ft}$, deep). In almost all cases, the linear relationship between $f_{t}$ and $\left(1 / F_{t}\right)$ is unacceptable (except for this one location), making the Horton equation a more suitable tool for calculating expected infiltration for the dry wells.

\subsection{Factors Affecting Infiltration Rates}

The analyses of the infiltration data resulted in several interesting conclusions. One of the first issues noted by the field personnel when installing the water level recorders and observing the dry wells over time was that some of the locations experienced periodic (or continuous) long term standing water in the dry wells, indicating seasonal or permanent high water table conditions, or partially clogged dry wells.

Table 10 summarizes the dry well performance conditions observed during the monitoring program, including the length of monitoring, hydrograph behavior, and the presence of standing water (and the percentage of time when the dry well was dry).

In almost all cases, the general shapes of the recession limbs (water elevation drops with infiltration) are similar for all observations at the same site, including the hydrant tests. However, some changed with time, including several that indicated slower infiltration with more standing water conditions in the winter and spring. This may be due to SAR (sodium adsorption ratio) issues that result in dispersed clays from the high sodium content of snowmelt. Normally, snowmelt would not affect these units if only roof runoff is directed to the dry wells. However, if walkway or driveway runoff drains to dry wells, de-icing salts may be in the snowmelt, increasing the SAR and decreasing the infiltration rates.

Standing water was observed in the dry well at $87 / 89$ Tennyson Drive when sufficient time occurred to allow the water to reach a consistent minimum water level (about $0.9 \mathrm{~m}, 3 \mathrm{ft}$, deep). It is expected that this site very likely has a shallow water table condition. The drainage rates were very slow, so the interevent periods were not sufficiently long to enable drainage to the stable water level until after about a 2 week dry period. The slow drainage rate may have been caused by saturated conditions associated with groundwater mounding. Several sites (260 Hartshorn Drive, 7 Fox Hill Place and 142 Fairfield Drive) experienced periodic slowly draining conditions, mainly in the spring, that could have been associated with SAR problems. The slow infiltration rates could be due to poor soils (with the clays resulting in SAR problems), or saturated soil conditions. The other sites all had rapid drainage rates that were consistent with time.

Another obvious factor affecting the observed infiltration rates was that one or two of the locations had significantly higher infiltration rates than the other sites (all having no standing water issues). These sites were the ones indicated as having the highest surface infiltration rate potentials (even though the infiltration rates of the dry wells were mostly affected by the subsurface soil conditions, which were mapped as being similar A and B conditions for all locations). It is therefore expected that these locations had better subsurface soil conditions compared to the other sites, even though mapped as being similar.

The Township of Millburn infiltration rate characteristics were therefore separated into three conditions:

- A and B surface soils and having well drained A subsurface soils; 
Table 10 Summary of infiltration conditions with time.

\begin{tabular}{|c|c|c|c|c|c|c|c|}
\hline Location & Start date of series & End date of series & \# of dry well events & $\begin{array}{l}\% \text { of time dry } \\
\text { well was dry }\end{array}$ & Consistent shape with time? & Standing water after events? & Other comments \\
\hline 11 Woodfield Drive. & 0ct 11, 2009 & Dec 20, 2009 & $\begin{array}{l}1 \text { hydrant } \\
5 \text { rains (1 small rain } \\
\text { missing) } \\
1 \text { hydrant }\end{array}$ & $89 \%$ & Yes & $\begin{array}{l}\text { Quickly drained (within a day); No standing } \\
\text { water at any time }\end{array}$ & 15 hours total drainage time during hydrant test \\
\hline 15 Marion Drive. & June 17, 2010 & August 6, 2010 & $\begin{array}{l}5 \text { rains ( } 2 \text { small rains } \\
\text { missing) } \\
1 \text { hydrant }\end{array}$ & $71 \%$ & Yes & $\begin{array}{l}\text { Several days to drain. ;No standing water } \\
\text { at any time }\end{array}$ & 4.5 days total drainage time during hydrant test \\
\hline 383 Wyoming Avenue. & July 16, 2009 & October 14, 2009 & $\begin{array}{l}6 \text { rains ( } 2 \text { small rains } \\
\text { missing) }\end{array}$ & $81 \%$ & Yes & $\begin{array}{l}\text { Several days to drain if full; } \\
\text { No standing water at any time }\end{array}$ & 1 day total drainage time during hydrant test \\
\hline 258 Main Street & June 16, 2010 & August 5, 2010 & $\begin{array}{l}5 \text { rains ( } 2 \text { smaller } \\
\text { rains missing) }\end{array}$ & $98 \%$ & Yes & $\begin{array}{l}\text { Very rapid drainage time; } \\
\text { No standing water at any time }\end{array}$ & \\
\hline 260 Hartshorn Drive & August 9, 2010 & August 1, 2011 & Many & $10 \%$ & Yes & $\begin{array}{l}\text { Slow drainage time (about a week if full), } \\
\text { but dry if given enough time between rains }\end{array}$ & $\begin{array}{l}\text { Clogging or poor soils, not high water table. Possible } \\
\text { SAR issues in the Winter and Spring, recovered by } \\
\text { mid-summer. }\end{array}$ \\
\hline 2 Undercliff Road & July 18, 2009 & October 6, 2009 & $\begin{array}{l}1 \text { hydrant } \\
3 \text { rains }\end{array}$ & $79 \%$ & Yes & $\begin{array}{l}\text { Several days to drain if full; } \\
\text { No standing water at any time } \\
\text { Very slow drainage time (a couple of weeks); }\end{array}$ & $\begin{array}{l}10 \text { days total drainage time during hydrant test } \\
\text { Slow drainage may be due to saturated conditions, }\end{array}$ \\
\hline 87/89 Tennyson Drive & August 10, 2010 & August 5, 2011 & Many & $0 \%$ & CYes & $\begin{array}{l}\text { standing water and never dry during this } \\
\text { period }\end{array}$ & $\begin{array}{l}\text { never reached stable low water level. If due to SAR, did } \\
\text { not recover. }\end{array}$ \\
\hline 7 Fox Hill Place & August 7, 2010 & March 23, 2011 & Many & $2 \%$ & & & \\
\hline 8 South Beechcroft & July 19, 2009 & September 27, 2009 & $\begin{array}{l}1 \text { hydrant } \\
6 \text { rains }\end{array}$ & $71 \%$ & $\begin{array}{l}\text { Consistent shape with time for } \\
\text { rains, but hydrant test (at end of } \\
\text { monitoring period at end of Sept) } \\
\text { was very rapid }\end{array}$ & $\begin{array}{l}\text { Quickly drained (within a day or two if full); } \\
\text { No standing water at any time }\end{array}$ & $\begin{array}{l}3 \text { hours total drainage time (half full) during hydrant } \\
\text { test }\end{array}$ \\
\hline 142 Fairfield Drive & August 10, 2010 & March 4, 2011 & 3 rains & $66 \%$ & $\begin{array}{l}\text { Somewhat inconsistent shape } \\
\text { with time }\end{array}$ & $\begin{array}{l}\text { Quickly drained (within a day or two if full) } \\
\text { to poorly drained (a week for moderate } \\
\text { rains); Standing water during periods of } \\
\text { large and frequent rains } \\
\text { Very rapid drainage time; } \\
\text { No standing water at any time }\end{array}$ & $\begin{array}{l}\text { Slowly drained conditions in Spring likely due to } \\
\text { saturated conditions, or SAR. Not likely due to high } \\
\text { water table }\end{array}$ \\
\hline
\end{tabular}

- C and D surface soils and having well drained $A$ and B subsurface soils; and

- C and D surface soils and having poorly drained $A$ and $B$ subsurface soils with long-term standing water.

Table 11 compares the observed Horton equation coefficients for the sites having well drained subsurface soils with equation coefficients that have been reported in the literature. The standing water data are not used in these calculations as most of the observations could not be successfully fitted to the Horton equation. The almost steady infiltration rates (but with substantial variation) were all very low for those conditions and only re The very large observed $f_{o}$ value ( $45 \mathrm{in} . / \mathrm{h}, 1130 \mathrm{~mm} / \mathrm{h}$ ) for the $A$ and $B$ surface soil sites that are well drained is greater than any of the reported literature values, and only approaches the observations for the non-compacted sandy soil conditions (34 in./h, $860 \mathrm{~mm} / \mathrm{h}$ ) observed by Pitt et al. (1999). The subsurface soil conditions affecting the dry well infiltration rates are likely natural with little compaction. Also, the subsurface soils at that location are noted as being sandy loam (A) and stratified gravelly sand to sand to loamy sand $(A)$. The other sites having smaller $f_{o}$ rates (4.3 in./h, $110 \mathrm{~mm} / \mathrm{h}$ ) are described as gravelly sandy loam (A) and fine sandy loam (B) and are similar to many of the reported literature values for sandy soils, with some compaction. present the $f_{c}$ values.
Table 11 Observed and reported Horton equation coefficients.

\begin{tabular}{|c|c|c|c|}
\hline & $\begin{array}{c}f_{0} \\
\text { (in./h) }\end{array}$ & $\begin{array}{c}f_{c} \\
\text { (in./h) }\end{array}$ & $\begin{array}{c}k \\
(1 / \mathrm{min})\end{array}$ \\
\hline $\begin{array}{l}\text { Surface } A \text { and B soils well drained } A \text { subsurface soils (average } \\
\text { and }(O V \text { ) }\end{array}$ & $\begin{array}{c}44.6 \\
(0.53)\end{array}$ & $5.6(0.2)$ & $\begin{array}{c}0.06 \\
(0.22)\end{array}$ \\
\hline $\begin{array}{l}\text { Surface }(\text { and } D \text { soils well drained } A \text { and B subsurface soils } \\
\text { (average and } \mathrm{COV} \text { ) }\end{array}$ & $4.3(0.64)$ & $\begin{array}{c}0.45 \\
(0.85)\end{array}$ & $\begin{array}{c}0.01 \\
(0.63)\end{array}$ \\
\hline UDFCD (2001) A soils (average) & 5.0 & 1.0 & 0.04 \\
\hline UDFCD (2001) B soils (average) & 4.5 & 0.6 & 0.11 \\
\hline UDFCD (2001) C and D soils (average) & 3.0 & 0.5 & 0.11 \\
\hline Pitt et al. (1999) Clayey, dry and non-compacted (median) & 11 & 3 & 0.16 \\
\hline Pitt et al. (1999) Clayey, other (median) & 2 & 0.25 & 0.06 \\
\hline Pitt et al. (1999) Sandy, compacted (median) & 5 & 0.5 & 0.1 \\
\hline Pitt et al. (1999) Sandy, non-compacted (median) & 34 & 15 & 0.08 \\
\hline Akan (1993) Sandy soils with little to no vegetation & 5 & & \\
\hline Akan (1993) Dry loam soils with little to no vegetation & 3 & & \\
\hline Akan (1993) Dry clay soils with little to no vegetation & 1 & & \\
\hline Akan (1993) Moist sandy soils with little to no vegetation & 1.7 & & \\
\hline Akan (1993) Moist loam soils with little to no vegetation & 1 & & \\
\hline Akan (1993) Moist clay soils with little to no vegetation & 0.3 & & \\
\hline
\end{tabular}

The large $f_{c}$ value $(5.6 \mathrm{in} . / \mathrm{h}, 140 \mathrm{~mm} / \mathrm{h}$ ) observed for the well drained A and B surface soil location is bracketed by the non-compacted clayey and sandy soil conditions (3in./h, $80 \mathrm{~mm} / \mathrm{h}$, and $15 \mathrm{in.} / \mathrm{h}, 380 \mathrm{~mm} / \mathrm{h}$ ) reported by Pitt et al. (1999), but is substantially larger than the other reported values. The $f_{c}$ 
value observed for the well drained $C$ and $D$ surface soil site $(0.45$ in./h, $11 \mathrm{~mm} / \mathrm{h})$ is similar to the other reported values $(0.50 \mathrm{in} . / \mathrm{h}$, $13 \mathrm{~mm} / \mathrm{h}$, to $1.0 \mathrm{in} . / \mathrm{h}, 25 \mathrm{~mm} / \mathrm{h}$ ). The $k$ first order rate coefficient values $(0.011 / \mathrm{min}$ and $0.061 / \mathrm{min})$ are similar, but on the low side, of the reported values $(0.041 / \mathrm{min}$ to $0.111 / \mathrm{min})$.

In order to most accurately design dry well installations in an area, site observations of the expected infiltration rates should be used instead of general literature values. This is especially true for surface infiltration devices (such as rain gardens), where compaction due to construction activities and general urban use will have a much greater effect than on the deeper subsurface soils. Also, all of the sites in this study had improved infiltration characteristics with depth compared to expected surface conditions; in other cases, this may not be true. Criteria based only on surface soil conditions are likely not good predictors of deeper dry well performance. Luckily, county soil surveys do have some subsurface soil information that was found to be generally accurate during this study. Unfortunately, shallow water table conditions are not well known for the area and that characteristic can have a significant detrimental effect on observed dry well performance.

\subsection{Water Quality Observations}

The samples were analyzed in laboratories of the University of Alabama for bacteria (total coliforms and E. coli), total nitrogen (TN), nitrate plus nitrite ( $\mathrm{NO}_{3}$ plus $\mathrm{NO}_{2}$ ), total phosphorus (TP), and chemical oxygen demand (COD). Lead, copper and zinc were analyzed at a commercial laboratory (Stillbrook Environmental Testing Laboratory in Fairfield, Alabama).

A number of complementary statistical analyses of the water quality data were conducted using MINITAB and MS Excel software, including log-normal probability plots, Anderson-Darling (AD) $p$ test for normality, group box plots, paired line plots, time series plots, and Mann-Whitney comparison tests (or the paired sign test for metals due to large fractions of non-detected observations).

Table 12 lists the output obtained using MINITAB for nonparametric Mann-Whitney comparisons between paired data. Except for the bacteria and COD results for the cistern site, as noted previously, all paired sample sets did not indicate significant differences for these numbers of samples at the 0.05 level for the numbers of sample pairs available.

Table 13 lists the results for the paired sign test (used because of numerous non-detected values) for lead, copper and zinc observations for the cistern and dry well samples. No statistically significant differences were seen between the sample sets for the heavy metals for the numbers of samples available.

Statistical analyses indicated that the differences in water quality between the shallow and the deeper samples were not significant for the number of sample pairs available ( $p$-values were $>0.05$ ). However, significant differences were found $(p<0.05)$ between the quality of inflow samples and cistern samples for total coliforms (possible re-growth), E. coli, and COD (concentration reductions). More samples would enable the identification of significant differences at smaller differences in concentrations. During this research, the minimum detected significant differences (for $95 \%$ confidence and $80 \%$ power) are quite large ( $>50 \%)$ for most of the constituents and locations, while the actual observed differences were small $(<50 \%)$.

These findings indicate that the dry wells do not significantly change the water quality for most of the stormwater constituents. If the influent water quality is good, the dry wells can be a safe disposal method for stormwater. However, most of the bacteria and lead concentrations exceeded the groundwater disposal criteria for New Jersey and may require treatment if the aquifer is critical.

Table 12 Summary of Mann-Whitney tests for paired data.

\begin{tabular}{|c|c|c|c|c|c|}
\hline \multirow{2}{*}{ Parameter } & & 79 Inflow vs & 135 Shallow vs & 18 Shallow vs & 139 Shallow vs \\
\hline & & 79 Cistern & 135 Deep & 18 Deep & 139 Deep \\
\hline \multirow{7}{*}{$\begin{array}{l}\text { Total } \\
\text { Coliforms }\end{array}$} & $p$-value & 0.03 & 0.40 & 0.16 & 0.72 \\
\hline & & $\begin{array}{l}\text { Yes (but } \\
\text { cistern median }\end{array}$ & & & \\
\hline & Significant Differ- & & & & \\
\hline & $\begin{array}{l}\text { ence Ubserved? (at } \\
\text { level of } 0.05 \text { ) }\end{array}$ & $\begin{array}{l}\text { larger than } \\
\text { the inflow }\end{array}$ & No & No & No \\
\hline & & median & & & \\
\hline & & values) & & & \\
\hline & $p$-value & 0.05 & 0.60 & 0.69 & 1 \\
\hline \multirow{5}{*}{ E. coli } & & Yes (cistern & & & \\
\hline & Significant Differ- & median values & & & \\
\hline & ence Observed? (at & $\begin{array}{l}\text { significantly } \\
\text { less than the }\end{array}$ & No & No & No \\
\hline & level of 0.05) & inflow median & & & \\
\hline & & values) & & & \\
\hline \multirow{3}{*}{$\begin{array}{l}\text { Total } \\
\text { Nitrogen } \\
\text { as } \mathrm{N}\end{array}$} & $p$-value & 0.86 & 0.50 & 0.42 & 0.64 \\
\hline & Significant Differ- & & & & \\
\hline & $\begin{array}{l}\text { ence Observed? (at } \\
\text { level of } 0.05 \text { ) }\end{array}$ & No & No & No & No \\
\hline \multirow{3}{*}{$\begin{array}{l}\mathrm{NO}_{3} \text { plus } \\
\mathrm{NO}_{2}-\mathrm{N}\end{array}$} & $p$-value & 0.14 & 0.24 & 0.15 & 0.77 \\
\hline & Significant Differ- & & & & \\
\hline & $\begin{array}{l}\text { ence Observed? (at } \\
\text { level of } 0.05 \text { ) }\end{array}$ & No & No & No & No \\
\hline \multirow{3}{*}{$\begin{array}{l}\text { Total Phos- } \\
\text { phorus } \\
\text { as P }\end{array}$} & $p$-value & 0.77 & 0.94 & 0.10 & 0.27 \\
\hline & Significant Differ- & & & & \\
\hline & $\begin{array}{l}\text { ence Observed? (at } \\
\text { level of } 0.05 \text { ) }\end{array}$ & No & No & No & No \\
\hline \multirow{6}{*}{ COD } & $p$-value & 0.04 & 0.14 & 0.40 & 0.83 \\
\hline & & Yes (cistern & & & \\
\hline & Significant Differ- & median values & & & \\
\hline & ence Observed? (at & $\begin{array}{l}\text { Significantly } \\
\text { less than the }\end{array}$ & No & No & No \\
\hline & level of 0.05 ) & inflow median & & & \\
\hline & & values) & & & \\
\hline
\end{tabular}


Table 13 Summary of paired sign test for metal analysis.

\begin{tabular}{|c|c|c|c|c|c|}
\hline Metal & & $\begin{array}{c}79 \text { Inflow vs } \\
79 \text { Cistern }\end{array}$ & $\begin{array}{l}135 \text { Shallow } \\
\text { vs } 135 \text { Deep }\end{array}$ & $\begin{array}{l}18 \text { Shallow } \\
\text { vs } 18 \text { Deep }\end{array}$ & $\begin{array}{l}139 \text { Shallow } \\
\text { vs } 139 \text { Deep }\end{array}$ \\
\hline \multirow{2}{*}{ Lead } & $\mathrm{p}$-value & $>0.06$ & $>0.06$ & 0.18 & $>0.06$ \\
\hline & Significant Difference in Medians? & No & No & No & No \\
\hline \multirow{2}{*}{ Copper } & $\mathrm{p}$-value & 0.13 & * & $>0.06$ & * \\
\hline & Significant Difference in Medians? & No & * & No & * \\
\hline \multirow{2}{*}{ Zinc } & $\mathrm{p}$-value & 0.45 & 0.45 & $>0.06$ & $>0.06$ \\
\hline & Significant Difference in Medians? & No & No & No & No \\
\hline
\end{tabular}

* all non-detected.

\subsection{Standing Water Conditions in Monitored Dry Wells}

Figure 8 is a map showing the general infiltration rate conditions for Millburn, as monitored during this project. Most of the monitored dry wells were along a ridge between the two main drainages of the township, with no obvious pattern of high water conditions, except that the high standing water dry wells were located along a line to the southwest along the ridge and are lo- cated fairly close to the headwaters of streams. (High water tables were noted in areas with nearby streams, but that was assumed to be in the larger stream valleys and not at the headwaters).

The sites that had high standing water long after the events ended had substantially reduced infiltration rates. In the analyses, these rates were considered to be the constant (final) rates observed, with no initial rate data or first order decay Horton coefficients used (relatively constant, but very low infiltration rates). Three of the sites had severely degraded infiltration conditions (260 Hartshorn Drive, 87/89 Tennyson Drive, and 7 Fox Hill Place). These sites all received runoff from the entire property or from multiple impervious areas (and are $1 \mathrm{y}$ to $5 \mathrm{y}$ old). It is not known if the source water or groundwater conditions affected the drainage conditions at these sites. Dry wells receiving runoff from all impervious areas would have a greater silt load and likely clog prematurely compared to sites only receiving roof runoff.

Even sites having surface $C$ and $D$ soils (not acceptable infiltration sites according to the New Jersey dry well standards) had much better subsurface conditions where the dry wells were located than were the surface conditions. The infiltration rates for these conditions were less than for the excellent areas having $A$

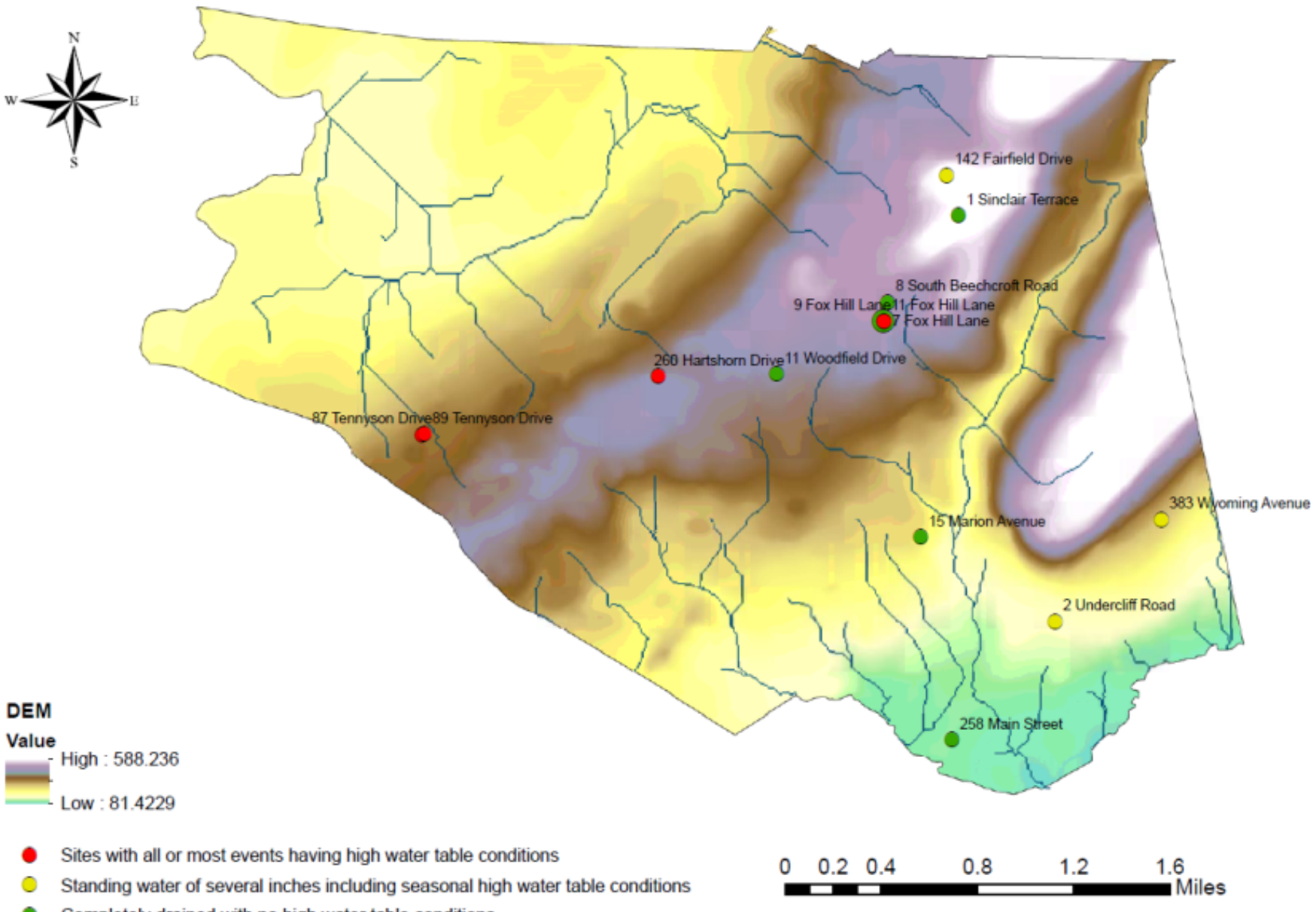

Figure 8 Township map showing locations having varying standing water conditions in monitored dry wells. 
and $B$ surface soils, but all met the infiltration rate criteria of the state guidelines.

Table 14 lists the most stringent regulatory levels for groundwater contaminants derived from N.J.A.C. 7:9C (NJDEP 2011), along with the range of observed concentrations for each constituent during these tests. The microbiological and lead concentrations frequently exceeded the groundwater disposal criteria.

Table 14 Groundwater quality criteria for the state of New Jersey compared to observed water quality from dry wells.

\begin{tabular}{|c|c|c|c|}
\hline Constituent & $\begin{array}{l}\text { Groundwater Quality } \\
\text { Criterion }{ }^{1}\end{array}$ & Observed Range ${ }^{1}$ & $\begin{array}{c}\text { Fraction of samples that } \\
\text { exceed the criteria }\end{array}$ \\
\hline $\begin{array}{l}\text { Microbiological } \\
\text { criteria }^{2}\end{array}$ & $\begin{array}{l}\text { Standards promulgated } \\
\text { in the Safe Drinking } \\
\text { Water Act Regulations } \\
\text { (N.J.A.C. 7:10-1 et seq.) }\end{array}$ & $\begin{array}{l}\text { Total coliform: } \\
1 \text { to } 36294 \mathrm{MPN} / 100 \mathrm{~mL} \\
\text { E. coli: } 1 \text { to } 8469 \\
\text { MPN/100 mL }\end{array}$ & $\begin{array}{l}\text { Total coliform: } 63 \text { of } \\
71 \text { samples exceeded } \\
\text { the criterion for total } \\
\text { coliforms }\end{array}$ \\
\hline Nitrate and Nitrite & 10 & $\begin{array}{l}0.0 \text { to } 16.5 \\
\text { (one sample had a } \\
\text { concentration of } 16.5 \\
\mathrm{mg} / \mathrm{L} \text { ) }\end{array}$ & $\begin{array}{l}\text { 1of } 71 \text { samples exceeded } \\
\text { the criterion for nitrates } \\
\text { plus nitrites }\end{array}$ \\
\hline Nitrate & 10 & 0.1 to 4.7 & 0 \\
\hline Phosphorus & $\mathrm{n} / \mathrm{a}$ & 0.02 to 1.36 & $\mathrm{n} / \mathrm{a}$ \\
\hline COD & $\mathrm{n} / \mathrm{a}$ & 5.0 to 148 & $\begin{array}{l}n / a \\
33 \text { of } 71 \text { samples }\end{array}$ \\
\hline Lead & 0.005 & BDL to 0.38 & $\begin{array}{l}\text { exceeded the criterion } \\
\text { for lead }\end{array}$ \\
\hline Copper & 1.3 & BDL to 1.1 & 0 \\
\hline Zinc & 2.0 & BDL to 0.14 & 0 \\
\hline $\begin{array}{l}{ }^{1} \text { Ground water qual } \\
2 \text { Pursuant to prevail } \\
\text { in violation of the } \mathrm{M} \\
{ }^{3} 50 \mathrm{MPN} / 100 \mathrm{~mL}\end{array}$ & $\begin{array}{l}\text { ity criteria and observed ra } \\
\text { ling Safe Drinking Water A } \\
\text { ICL and is therefore an exc }\end{array}$ & $\begin{array}{l}\text { ge are expressed as } \mathrm{mg} / \\
\text { Regulations any positive } \\
\text { dance of the groundwat }\end{array}$ & $\begin{array}{l}\text { unless otherwise noted. } \\
\text { result for fecal coliform is } \\
\text { quality criteria. }\end{array}$ \\
\hline
\end{tabular}

Reference evapotranspiration (ET) rates for the Millburn area range from about $0.4 \mathrm{~mm} /$ day (0.015 in./day) during January to about $4 \mathrm{~mm} / \mathrm{h}(0.16 \mathrm{in} . / \mathrm{h})$ during May through July. The period of maximum ET also corresponds to the period of maximum rainfall in the area, reducing the need for irrigation (and also the sizes of long term water storage tanks). Therefore, the beneficial use of roof runoff for irrigation is limited if it is used only to meet the irrigation demand. However, irrigation can also be used as a stormwater management option with excess water being used to recharge the shallow groundwater and to meet the increased moisture needs of some heavily watered lawns (such as common Kentucky Bluegrass).

\section{Conclusions}

Dry wells may be a preferred option in cases that are allowed by the New Jersey dry well disposal regulations for stormwater (NJDEP 2004) which limits their use to areas having excellent soils (HSG A or B), where the groundwater table is below the dry well system (to prevent standing water in the dry wells and very slow infiltration), and to only receive roof runoff water (generally the best quality runoff from a site and not contaminated with deicing salts). However, the beneficial uses of roof runoff should be the preferred option, and in many cases may be less costly, especially considering increasing water utility rates and the desire to conserve highly treated domestic water supplies. Shallow groundwater recharge may be an important objective for an area, but over-irrigation (beyond the plants evapotranspiration, ET, deficit needs, but less than would produce direct runoff) would also contribute to that objective, at the same time as conserving water and offering better groundwater protection.

Rain gardens are another viable alternative for stormwater management in the Millburn area, especially as they provide some groundwater quality protection and can be incorporated into the landscaping plan of the site. They likely require additional maintenance; similar to any garden, but they can be placed to receive runoff from several of the source areas on a site, increasing the overall stormwater management level. They have even been incorporated along roads, as curb-cut biofilters, resulting in significant overall runoff volume reductions (but with special care to prevent premature clogging, reduced salt discharges, and appropriately sized to handle the large flow volumes).

Alternative stormwater options should be used when dry well use should be restricted, such as with the following conditions:

poor infiltration capacity of subsurface soil layers; concerns about premature clogging or other failures due to sediment; discharges or snowmelt discharges to dry wells;

- seasonal or permanent high water tables; and,

- concerns about groundwater contamination potential.

\section{Acknowledgments}

The information reported in this paper was funded by the Urban Watershed Management Branch, U.S. Environmental Protection Agency, Edison, NJ, 08837 as part of the project Evaluation and Demonstration of Stormwater Dry Wells and Cisterns in Milburn Township, New Jersey (EP-C-08-016). Some of the materials presented in this paper were first published in the USEPA report (Pitt and Talebi 2012). The authors would like to thank Mel Singer, consultant and resident of Millburn Township, the Township of Millburn personnel (especially Thomas Watkinson, Millburn Township Engineer, Tim Gordon, Township Manager, Sandra Haimoff, Mayor, Martha Annoi, and others), the homeowners who allowed access for the study sites, and especially to the PARS Environmental, Inc. 
personnel (Ramjee Raghavan and Hunter Blair, and others). The authors would like to especially thank Richard Field, Mary Stinson, Anthony N. Tafuri and Sivajini Gilchrist who provided the USEPA funding and directed the project through the U.S. Environmental Protection Agency.

\section{References}

Akan, A. O. 1993. Urban Stormwater Hydrology: A Guide to Engineering Calculations. Lancaster, PA: Technomic.

Bedient, P. B., and W. C. Huber. 1992. Hydrology and Foodplain Analysis. Reading, MA: Addison-Wesley.

Green, W. H. and G. A. Ampt. 1911. "Studies on Soil Physics: I. Flow of Air and Water through Soils." Journal of Agricultural Science 4:1-24.

Horton, R. E. 1940. "An Approach Toward a Physical Interpretation of Infiltration Capacity." Soil Science Society of America Proceedings 5:399-417.

Leila Talebi University of Alabama, Tuscaloosa, AL.

Robert Pitt University of Alabama, Tuscaloosa, AL.
NJDEP (New Jersey Department of Environmental Protection). 2004. Chap. 9.3 (Standard for Dry Wells) and chap. 9.5 (Standard for Infiltration Basins) in New Jersey Stormwater Best Management Practices Manual. Trenton, NJ: NJDEP. http://www.njstormwater.org/index.html.

NJDEP (New Jersey Department of Environmental Protection). 2011. New Jersey Surface Water Quality Standards (N.J.A.C. 7:9B). Trenton, NJ: NJDEP. http://www.state.nj.us/dep/wms/bwqsa/docs/njac79C.pdf.

Pitt, R., J. Lantrip, R. Harrison, C. Henry and D. Hue. 1999. Infiltration through Disturbed Urban Soils and Compost-Amended Soil Effects on Runoff Quality and Quantity. Washington, DC: U.S. Environmental Protection Agency. EPA 600/R-00/016.

Pitt, R. and L. Talebi. 2012. Evaluation and Demonstration of Stormwater Dry Wells and Cisterns in Milburn Township, New Jersey. Washington, DC: U.S. Environmental Protection Agency.

UDFCD (Urban Drainage and Flood Control District). 2001. Urban Stormwater Drainage Criteria Manual, Vols. 1 and 2. Denver, CO: UDFCD. 